\title{
A study of project managers' choice on key methods, tools and techniques in managing engineering projects
}

DOI 10.2478/otmcj-2021-0002

Received: December 17, 2019; Accepted: January 12, 2021

\begin{abstract}
There is no doubt that each project manager uses different methodologies, methods, tools and techniques (MMTTs) while dealing with constant pressure to deliver results in a complex and changing environment, where complexity and stakeholders' expectations are continually growing. This article presents results from the study about project managers' choice on artefacts that they frequently use in their regular work. This study was conducted within the context of selected environment (one country and one sector of engineering projects), but designed methodology and results might also be significant for a wider audience. The results were based on the feedback that were received from 31 project management (PM) professionals gathered in the form of a structured questionnaire, followed by an interview with three PM experts for validation. The results confirmed a variety of PM artefacts in use and provided their ranking by perceived usefulness. The additional results indicated correlation between PM success and usage of MMTTs, as perceived by project managers. This study also resulted in several interesting findings, such as popularity and usefulness of artefacts, rigidity of PM processes, and maturity of PM organizations, about the topic. Despite of rather small sample taken from one country's environment, the results could serve as a solid information for moving ahead, while considering the significance of PM artefacts, as well as for their further development. The key findings are also messages to PM professionals to
\end{abstract}

The paper is extended version of conference paper published at proceedings of Creative Construction Conference 2019, CCC 2019, 29 June-2 July 2019, Budapest, Hungary

\footnotetext{
*Corresponding author: Mladen Radujković, Croatian Association for Project Management, Croatia; Alma Mater Europea ECM, Slovenska ulica 17, Maribor 2000, Slovenia. E-mail: mladen@projectexpert.hr

Mariela Sjekavica Klepo, Hrvatske vode, Zagreb, Croatia
}

consider whether they use available and appropriate PM artefacts and is there a room for more efficient and effective usage.

Keywords: Croatia, methods, project management, success, techniques, tools, usage, water infrastructure

\section{Introduction}

Recent studies about projectification confirmed that about one-third of businesses within economy in almost any country is designed and executed as projects (IPMA 2018). The volume of project work measured by hours is permanently increasing (IPMA 2018; Nieto 2012), so the contribution of projects in total work volume is permanently growing. Previous study about projectification of economy stated that there are about 1,500 published papers confirming growth of project job compared with standard line work (Schoper et al. 2018). This is not only the case in project-oriented sectors such as construction or IT, but also in diverse spectrum of production-oriented businesses, so Jensen et al. (2016) in their study proclaimed "projectification of everything." In many organizations, projects are linked to the strategy and serve as a tool for converting opportunities to benefits. It seems that projects are appropriate instruments of changes, adaption, innovation and delivery. While in project-oriented sectors project deliverables are usually handed over to external party (owner, buyer or user) (Morris 2013a) or simply sold on the market, in production and operation-oriented sectors projects are mostly drivers for implementation of internal changes, innovations and improvements, and therefore they serve as a fuel for the ongoing operations to obtain better results.

Having in mind that we live in a project world, regardless of the project final purpose, project success should be the ultimate goal for all parties involved. Project success is an eternal research topic and there are many studies that contributed to the body of knowledge over time 
(Albert et al. 2017; Zwikael and Meredith 2019). Despite of many contributions resulting from studies and improvements in the practices, organizations permanently set new agendas for the project success attributes and levels, so each new contribution for understanding and/ or increasing chances of successful project outcomes is interesting for all parties involved. There are many options how to do it, which reflects the complexity of the topic and also creates opportunities for researchers. Many research proved relationship between successful project management (PM) and project success (Collins and Baccarini 2004; Mir and Pinnington 2014; Serrador and Turner 2015), which directs us to the PM area.

Significance and volume of project business enhance challenges to take PM profession to the next level, where all stakeholders point responsibility as the most important element for success from their perspective (Davis 2017; Liang et al. 2017). It is clear that PM role does not accompany responsibility for long-term project success due to many influences out of its responsibility. PM is rather responsible for successful delivery of project final product or service, and short-term perspective (Baccarini 1999; De Wit 1988; Munns and Bjeirmi 1996), where composition of PM success factors is a critical issue (Radujkovic and Sjekavica 2017). In such environment, each project manager is looking for the "magic formula" of PM success, with constant search of all components that might contribute to PM success. The challenges in PM success arise from the absence of copy-paste scenarios from the previous projects, since each project situation is different in many aspects (Morris 2002). Therefore, careful and justified selection of PM success components and their linkage in a functional composition is one of the critical tasks for each project manager and his or her team. The challenge is similar to dealing with project scope, in a sense of "bringing together all of the necessary components, and nothing beyond that." By doing so, each adequate component is important by itself, as well as its relation to the other components, totality and smooth functioning. Such observation is known from the theory of the systems (von Bertalanffy 1968), and it is valid in many complex scenarios. This fact opens several perspectives for observation and study of PM success.

The aim of this study was to investigate what are the most commonly used artefacts from PM arsenal (methodologies, methods, tools and techniques [MMTTs]) and what are the general opinions of project managers about contribution of such artefacts in their more successful work. By supporting work of project managers and making it more successful, those artefacts contribute to the success of PM, and consequently, as stated earlier, they also create certain contribution to project success, at least as being "one brick in the project success wall." This study was based on current state-of-the-art and local perspective of the developing PM community faced with growing number of projects. The representative sample was taken from one country (Croatia) and one sector that flourishes different projects, recently enlarged with a significantly increased number of projects due to the EU programmes and co-financing. There are many countries in central and south-east Europe, sharing similar environment, so results of this study might have a wider context.

Section 1 provides short literature review about the project success, and directions about recent PM developments and thoughts. It provides the context for this study and explains research gap and objective. Section 2 presents the literature review and the key findings related to the research objective. Section 3 describes the research design, while Section 4 explains shortlisting of the PM artefacts. The key results obtained from this study are presented in Section 5, immediately followed by discussion in Section 6. Limitations of this study and conclusions are provided in Sections 7 and 8.

\section{Literature review}

For years, PM profession had discussion - is it more about hard or soft skills, competences or proven methodologies, formality or agility, creativity or accountability, etc. (Hariharan and Arpasuteerat 2017; Van Casteren 2017; Zuo et al. 2018). It seems that currently we finally learnt that in a "magic formula of PM success" we need a pinch of everything, with an accent on the features that depend on project characteristics and context. Competent project managers are one of the PM success factors (Radujkovic and Sjekavica 2017; Sudhakar 2016), but to do their jobs properly they require supporting tools for their actions. Pillars that generally support PM success are PM MMTTs.

Proven PM techniques (as a way of carrying out particular task) make PM easier and more effective, regardless of project field or industry. Being applied via a PM tool (software), they save time and money (Project Management Blog 2019). PM tools (as objects used to extend ability), often considered as a PM software, are aids to assist an individual or team to effectively organize work and manage projects and tasks (Project Management Guide 2019). PM methodology is usually defined as a set of methods, techniques, procedures, rules, templates and best practices applied on a project. It is commonly based on a specific PM approach that defines a set of principles 
and guidelines which then defines the way a project is managed (Spundak 2014).

PM MMTTs are considered to be an important factor in successful work of each project manager (Besner and Hobbs 2008; Nahod et al. 2013). On the one hand they are unavoidable components in the regular work of a project manager, but on the other hand they might mislead project managers who totally rely on the horizon given by a particular MMTT. As said earlier, PM is a creative job, with little chance for successful copy-paste scenarios, and too much of "software-" or "tools"-driven approach can significantly damage creativity and intuition of a project manager which are well-known assets of PM competence (Blankevoort 1983; IPMA 2006; Leybourne and Sadler-Smith 2006). Although this mind sound as an oxymoron, it is rather a PM reality. There is even a term that combines the ability in achieving balance between hard and technical project requirements and creativity in adopting them via social behaviours and project environment expectations - ambidextrous PM (Crilly 2020). Nevertheless, in a competent project manager's hands, PM MMTTs are inevitable, strong and supportive component for managing towards success (Musa and Mohammed 2016).

The very first stage of modern PM was quite tied and dependable on MMTTs. As a matter of fact, early modern PM was primarily identified by planning and scheduling via network techniques, such as critical path method (CPM), project evaluation and review technique (PERT) or later precedence diagram method (PDM) (Tonchia 2018), followed by flourishing of different software solutions and tools, so as suggestions for optimization methods supported by IT solutions. However, the main problems of such optimal solutions remain the well-known "garbage in = garbage out" issue (Lordo 2001), and many of them remained only theoretically applied PM MMTTs. The next development phase resulted with much more promising MMTTs' deliverables, primarily within different proposals for PM methodologies, baselines, bodies of knowledge, guidelines, etc. Many theories, tools and techniques were integrated here and became relevant factor in the regular work of project managers worldwide. The most common and well-known PM global guidelines (could be referred to as "standards") are PMI's Project Management Body of Knowledge (PMI 2020) and IPMA's Competence Baseline for Individuals (IPMA 2006; IPMA 2015). In parallel, many internal or external PM methodologies and books were launched, some in commercial arrangement and some open-accessed. The relevant example of the latest is $E U$ $P M^{2}$ Methodology (European Commission 2018), where numerous tools were sorted within the project life cycle, including supportive artefacts supplemented by the corresponding templates. Earlier PM MMTTs' specialized book sorted dozens of tools across the management phases (Milosevic 2003). At present, MMTTs are omnipresent in PM life, so even references dealing with higher-level perspective of PM, such as Morris (2013b), provide an open room for MMTTs' role.

With everything said, an important open question is: What MMTTs are used and what is their usefulness? This research question is not new, and many researchers examined which MMTTs are used in different sectors, project types and countries (Doe 2017; Ismael and Raúl 2019; Musa and Mohammed 2016; Romero et al. 2018). Papke-Shields et al. (2010) showed widely varying usage of different PM practices and differences in usage, depending on the context of the project. This stresses the strong relationship between PM theory and practice, especially in the context of modern PM challenges (Alotaibi and Mafimisebi 2016). PM theory and practice can be interdependent only when PM theories are beneficial and can be applied (Alotaibi and Mafimisebi 2016).

Published work in 2020 (which were mostly an overview of previously published papers), so as many feedbacks from PM conferences, confirmed that all practitioners use particular PM MMTTs, such as those that are publicly available or designed internally, mixed or tailored. Most of the PM practitioners, particularly beginners, are highly dependable on such support in their regular work. They are keen to receive advertisements obtained from professional MMTT servicers or developers and to collect arsenal of MMTTs. A simple internet check shows that PM MMTTs market is huge, being represented by around 450 million of published results (Google search 2020), including many advertising notices and unproven statements. There is a significant increase in PM blogs recently, which also deal with the topic, where practitioners publish their signed opinion and positions. It can be expected that commercial MMTT market and Internet publishing will continue to grow in the future, due to permanent high demands. In such environment, independent academic or research studies might provide reliable information and show the possible options for practitioners. Google Scholar (2020) shows about 2 millions of published articles or books about the topic in total, where around 130,000 are published during the last 5 years. Many of those articles/ books are specialized for a particular sector (e.g. construction, IT) or focused to some narrower area inside the PM, while several deal with comparison of agile and waterfall approaches for particular case or sector. The search also showed that publications mostly deal with PM tools, followed by methods and techniques and methodologies, 
where the ratio in number of publications among these groups is 5:3:2 during the last 5 years.

Main findings from the two selected recent papers published in the similar regional environment like ours were related to the possibilities of the usage of globally known PM methodologies (Jovanovic and Beric 2018) and the level of usage of methods, techniques and tools in PM and their impact on project success (Doskocil 2015). The first paper mainly confirms findings widely known at the global level regarding usage of agile and waterfall methodologies. The second paper confirmed dependence "between the application of the integrated method of PM and its success," so as that most of the observed companies "use the technique of Gantt Chart and network diagram," while many of them use work breakdown structure (WBS) and CPM method, so as MS Project software (Doskocil 2015). Moreover, companies are challenged by frequent project cost and time overruns, and by selection of an adequate and proper usage of PM MMTTs.

While considering findings about MMTT topic, we agree with the relevant outcomes obtained from the research, but we do not share positions from the commercial publishing or internet articles about superiority of a particular MMTT. We also believe that there are significant differences in used MMTTs across the globe, so as by organizations and sectors. The only common trend is increasing demand in the future, so as evergreen questions - why have we not increased the ratio of PM success, and consequently - why have we not significantly increased the success rate of projects, when we have more and more MMTTs at our disposal?

\section{Research design}

The study about potential and usage of PM MMTTs arsenal in the specific context was inspired by the final results of research on contribution of PM profession advancement in potential increase in project success and contribution to the community development. This study is focused to the data source from the single country (Croatia), but there are several countries in the region of central or south-east Europe which share similar developments and history, so as some business and cultural values, therefore results could have wider impact. All these countries are faced with growing number of projects and requirements for increasing project success rates to support changes and achieve faster development of society. The research was done within one type of projects, specifically water infrastructure projects. The authors chose water infrastructure projects because of their great significance for a country, both on local and strategic levels, and also when speaking within the EU context. The importance of water and sewage systems as well as wastewater treatment plants construction and reconstruction is highlighted through European Union Directives (Directive 98/83/EC and Directive 91/271/EEZ) as well as national laws and global trends in many countries worldwide (Sjekavica Klepo and Radujkovic 2019). These infrastructure projects are not only technically, contractually, timely and financially complex, but also combine a larger set of social and environmental sustainability elements, mainly in achieving added value to the living standard of the end users. Therefore, the authors believed that such projects were a good example for scanning the situation on MMTTs usage and usefulness within the context of the selected country - in this case, Croatia.

To answer the research question on usage and usefulness of MMTTs in the specific national and project type context on the example of Croatian water infrastructure projects, a research was conducted.

Following the research objective described in Section 1 , five research questions are defined as follows:

1. Do PM professionals regularly use different MMTTs as a supportive element in the work?

2. Do current available MMTTs cover the needs of local PM profession?

3. Are the simplest MMTTs the most popular MMTTs in practice?

4. Although useful and supportive, could MMTTs sometimes reduce creativity in project managers' work, due to methodology/tools-driven approach in the work?

5. Do PM professionals believe that MMTTs make their job more successful?

The goal is reached throughout research methodology explained in addition (Figure 1). The first step was to define relevant MMTTs used in the current world of PM. This was undertaken through the desk research of the relevant publications on the field.

Then a survey was undertaken within the group of infrastructural project managers who were dealing with water projects. Project managers were chosen as a competent group because the authors wanted to explore relationship between real usage and usefulness of MMTTs within the group that uses them mostly (in some cases exclusively) - i.e. project managers. The sample was picked as non-randomized sample due to the inability to detect all project managers working on water infrastructure projects in Croatian context (there is no formal register or list of 


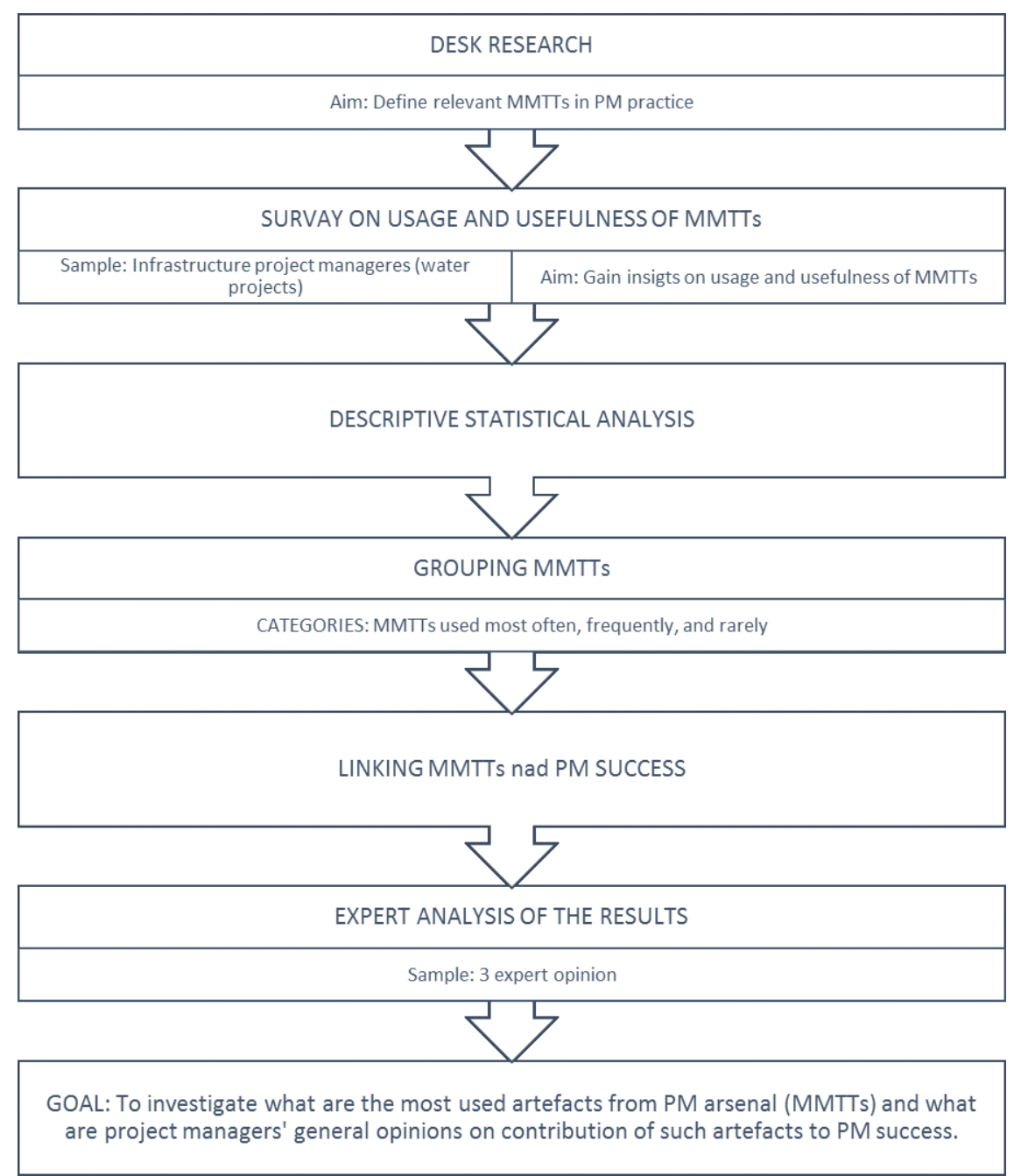

Fig. 1: Research methodology.

project managers in the sector). To include a larger set of competent project managers (from the governmental strategical, local - utility companies and operational site perspective), a snowball sampling was detected as a convenient method of sampling. The first 10 project managers in the sample came from the national agency for managing water resources. They were asked to detect next competent parties to fill the questionnaire and disseminate the questionnaire. By doing so, a total number of 31 project managers gave their insights on the research topic. This kind of sample was picked in accordance to Tkalac Vercic et al. (2014). Moreover, prior to gathering data from project managers, a check was done and all organizations they work for confirmed that each one of 31 project managers involved in this study is listed as successful due to the methodology used by their organizations. (Organizations use different methodologies for grading success of their project managers, and that was not the focus of this study due to its complexity and could be the object of the separate study.)

The sample was asked to give their insights on the level of usage and usefulness (efficiency) of each MMTT from the list created by previous desk research. In addition, they were asked whether they think that some new solutions in this field are needed while managing projects. Also, they were asked to grade PM success on their projects' portfolio. The results of the survey are given as an output of descriptive statistical analysis and grouping within categories of those inputs that are used most often, frequently and rarely, as well as linking those to PM success. Research results are then elaborated in context of current trends, other researchers work, experts' commentaries and answers on the meaning of present state on the field. Finally, conclusion remarks and guidelines for further research are given. These steps are explained in details in the following chapters. 


\section{Shortlisting the list of MMTTs}

There are numerous PM MMTTs nowadays. To find out an initial list of those that will be tested, the authors did a comprehensive literature review. In this research, earlier references from Fortune et al. (2011) and Jugdev et al. (2013) were taken. They also served as an element of PM success factors breakdown (Radujkovic and Sjekavica 2017). Those researchers divided PM MMTTs into six groups: PM methodologies, PM software, PM tools, decision-making techniques, risk assessment tools and information communication technology (ICT) support tools. From the initial list, some elements were taken out because they were not applicable in the national context of Croatia. Also, some of the elements that may be significant in this context were added based on the review of relevant literature (Drob and Zichil 2013; Ferreira et al. 2013; Patankul et al. 2010; Radujkovic et al. 2012). This list was also checked through references that were more timely relevant, i.e. newer ones (Dobie 2020; Hugo et al. 2018; Meredith et al. 2020). In such way, the final shortlist was composed which subsequently served as an input to a questionnaire (Table 1). The questions were focused on gathering information about which of these MMTTs are used, how supportive they are and are they simple and user friendly, so as are MMTTs contributor to the success of their work. The questions were structured according to the objective of this study and tested through the empirical part of this study.

\section{Survey and results}

The total number of 31 water infrastructure project managers answered the questionnaire on usage and usefulness of MMTTs. In accordance to sampling explained in Chapter 3, the survey was also answered by the project managers working in utility companies, contractors and consultants as well. Most of the respondents were male (65\%), between 31 and 40 years old (45\%), owning university degree ( $84 \%$ ) and having construction educational background (72\%). On average, respondents had 12 years of working experience, in which they worked on 5-6 projects. On average, managed project lasted for 2-3 years and had financial value of around 17 million EUR.

Respondents were asked if they think that used MMTTs on water projects are adequate in the sense of fulfilment of needs of PM for water sector. Then, respondents were given MMTTs list created through desk research (Chapter 4) in which they were supposed to check which MMTTs they use and grade their usefulness/efficiency on the Likert scale from 1 to 5 (where 1 = extremely not useful;
2 = not useful; 3 = nor not useful, nor useful; 4 = useful; 5 = extremely useful). Results were then divided into three groups of MMTTs: most often used (used by 13 respondents and more), frequently used (used by 5-12 respondents) and rarely used (used by 4 respondents and less). The results are presented in Table 1 and Figures 2-4. Table 1 combines data on $M$ (mean grade of usefulness) and frequency $f(n)$ (number of units in the sample using a given element).

The main results of the research are presented in graphical form in Figures 2-4. The results confirm that the most used MMTTs are those which are generally used for communication and administration of regular work, followed by those used for monitoring and control (Figure 2).

The frequently used MMTTs fall into a similar group of general artefacts that support communication (Figure 3).

Rarely used MMTTs are more sophisticated and more demanding for project managers (Figure 4).

The second part of survey was focused to find out which specific MMTTs project managers use and how they consider they contribute to their work success, as well as success of PM consequently. To do so, the questionnaire was composed of not only questions about MMTTs that were used and their perceived usefulness, but also project managers' grade on success of PM within their project's portfolio. As explained earlier, each project manager from the observed group of 31 was rated successful in his/ her organization by applying their internal verification methodology. Nevertheless, for additional check we used self-assessment grounded on International Competence Baseline (ICB) v.4.0 self-assessment logic (IPMA 2015). The check confirmed that all 31 project managers have PM competences for minimum level C, regardless of being certified or their usage of ICB or not. This confirmed us that all selected project managers are competent and understand PM and especially PM success.

So, the questionnaire was composed with a part on grading usefulness of each MMTT as well as a part on grading the PM success of selected projects by project managers. Five recent projects per project manager were observed. The grading was made on a Likert scale 1-5, where 1 stood for completely unsuccessful PM and 5 equalled to completely successful PM. For this study, PM success criteria were narrowed to the four ones, defined by time, budget, scope and quality constraints, which are represented in almost all studies dealing with engineering projects (Radujkovic and Sjekavica 2017). By doing so, a base for PM success self-evaluation per project manager was made. In parallel, we got each project manager's grades for each MMTT they use, considering usefulness and supportiveness on the line of success. 
Tab. 1: Perceived usefulness of used MMTTs

\begin{tabular}{|c|c|c|c|c|c|c|c|c|}
\hline Most often used MMTTs & $M$ & $f(n)$ & Frequently used MMTTs & $M$ & $f(n)$ & Rarely used MMTTs & $M$ & $f(n)$ \\
\hline $\begin{array}{l}\text { Integrated groupware } \\
\text { (email, collaborative tools, } \\
\text { shared access to web } \\
\text { portals, etc.) }\end{array}$ & 4.39 & 31 & $\begin{array}{l}\text { Other decision-making } \\
\text { techniques and tools }\end{array}$ & 4.14 & 7 & Agile board & 4.50 & 2 \\
\hline Lessons learned & 4.38 & 13 & Team building activities & 4.00 & 10 & Decision trees & 4.50 & 2 \\
\hline MS Excel & 4.29 & 31 & Decision analysis & 4.00 & 6 & $\begin{array}{l}\text { "In house" risk assessment } \\
\text { tools }\end{array}$ & 4.00 & 4 \\
\hline Cost-benefit analysis & 4.17 & 18 & Sensitivity analysis & 4.00 & 5 & Trend and variation analysis & 4.00 & 3 \\
\hline Reporting system & 4.05 & 22 & Communication plan & 3.91 & 11 & Earned value management & 4.00 & 2 \\
\hline Oracle Primavera & 4.00 & 16 & $\begin{array}{l}\text { “In house" project man- } \\
\text { agement tools }\end{array}$ & 3.91 & 11 & Critical chain method & 4.00 & 1 \\
\hline Groupware (email only) & 3.94 & 18 & $\begin{array}{l}\text { Voice over internet proto- } \\
\text { col (e.g. Skype) }\end{array}$ & 3.91 & 11 & Delphi method & 4.00 & 1 \\
\hline Gantt bar charts & 3.93 & 27 & $\begin{array}{l}\text { Project management } \\
\text { software developed "in } \\
\text { house" }\end{array}$ & 3.86 & 7 & Resource levelling & 4.00 & 1 \\
\hline Risk assessment & 3.92 & 13 & $\begin{array}{l}\text { Work breakdown struc- } \\
\text { ture }\end{array}$ & 3.86 & 7 & $\begin{array}{l}\text { Other risk assessment tools } \\
\text { and techniques }\end{array}$ & 3.75 & 4 \\
\hline Progress meetings & 3.90 & 31 & $\begin{array}{l}\text { Other project manage- } \\
\text { ment tools }\end{array}$ & 3.83 & 6 & $\begin{array}{l}\text { "What-if" scenario analysis - } \\
\text { Cause and effect diagrams }\end{array}$ & 3.67 & 3 \\
\hline Cash flow analysis & 3.90 & 20 & Microsoft Project & 3.75 & 8 & $\begin{array}{l}\text { PMBOK }^{\circledR} \text { (Project Management } \\
\text { Body of Knowledge) }\end{array}$ & 3.50 & 4 \\
\hline $\begin{array}{l}\text { "In house" communica- } \\
\text { tion and reporting system }\end{array}$ & 3.89 & 18 & Critical path method & 3.75 & 8 & SAP & 3.50 & 2 \\
\hline Checklist analysis & 3.87 & 23 & $\begin{array}{l}\text { Other information com- } \\
\text { munication technology } \\
\text { support tools }\end{array}$ & 3.73 & 11 & Monte Carlo simulation & 3.50 & 2 \\
\hline Progress reports & 3.86 & 29 & Life cycle cost analysis & 3.71 & 7 & Reliability analysis & 3.50 & 2 \\
\hline $\begin{array}{l}\text { PM methodology devel- } \\
\text { oped "in house" }\end{array}$ & 3.74 & 19 & Video conferencing & 3.71 & 7 & $\begin{array}{l}\text { Other project management } \\
\text { software }\end{array}$ & 3.33 & 3 \\
\hline Trend diagrams/S curves & 3.71 & 14 & $\begin{array}{l}\text { Other project manage- } \\
\text { ment methodologies }\end{array}$ & 3.70 & 10 & Probability and effect matrix & 3.33 & 3 \\
\hline \multirow[t]{10}{*}{ Project goals charter } & 3.67 & 15 & $\begin{array}{l}\text { Strengths, weaknesses, } \\
\text { opportunities and threats } \\
\text { analysis }\end{array}$ & 3.60 & 10 & $\begin{array}{l}\text { ISO } 21500: 2012-\text { Guidance } \\
\text { on project management }\end{array}$ & 3.00 & 3 \\
\hline & & & $\begin{array}{l}\text { Project evaluation and } \\
\text { review technique }\end{array}$ & 3.60 & 5 & Stakeholder analysis & 3.00 & 3 \\
\hline & & & Flow diagrams & 3.60 & 5 & Fault tree analysis & 3.00 & 2 \\
\hline & & & Probability analysis & 3.57 & 7 & Hazard and operability studies & 2.50 & 2 \\
\hline & & & $\begin{array}{l}\text { "In house" decision- } \\
\text { making techniques and } \\
\text { tools }\end{array}$ & 3.56 & 9 & Hazard analysis & 2.50 & 2 \\
\hline & & & $\begin{array}{l}\text { International Competence } \\
\text { Baseline }\end{array}$ & 3.50 & 6 & $\begin{array}{l}\text { Agile project management } \\
\text { methodologies }\end{array}$ & 1.00 & 1 \\
\hline & & & $\begin{array}{l}\text { Communities of practice } \\
\text { enabling tools (profes- } \\
\text { sional forums, etc.) }\end{array}$ & 3.45 & 11 & & & \\
\hline & & & $\begin{array}{l}\text { Organizational break- } \\
\text { down structure }\end{array}$ & 3.40 & 5 & & & \\
\hline & & & $\begin{array}{l}\text { Precedence diagram } \\
\text { method }\end{array}$ & 3.33 & 9 & & & \\
\hline & & & Risk register & 2.83 & 6 & & & \\
\hline
\end{tabular}




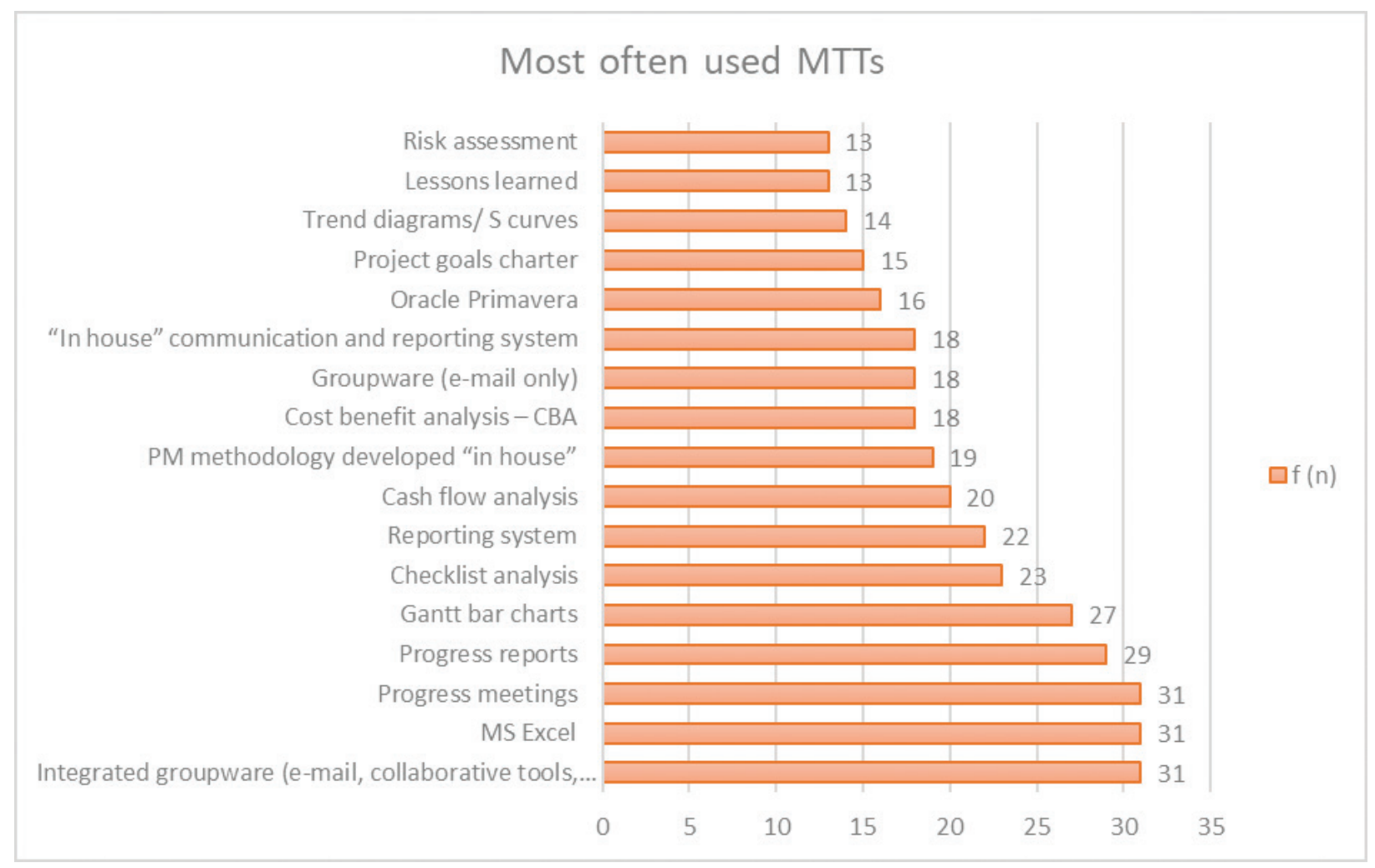

Fig. 2: Most often used MMTTs.

\section{Frequently used MTTs}

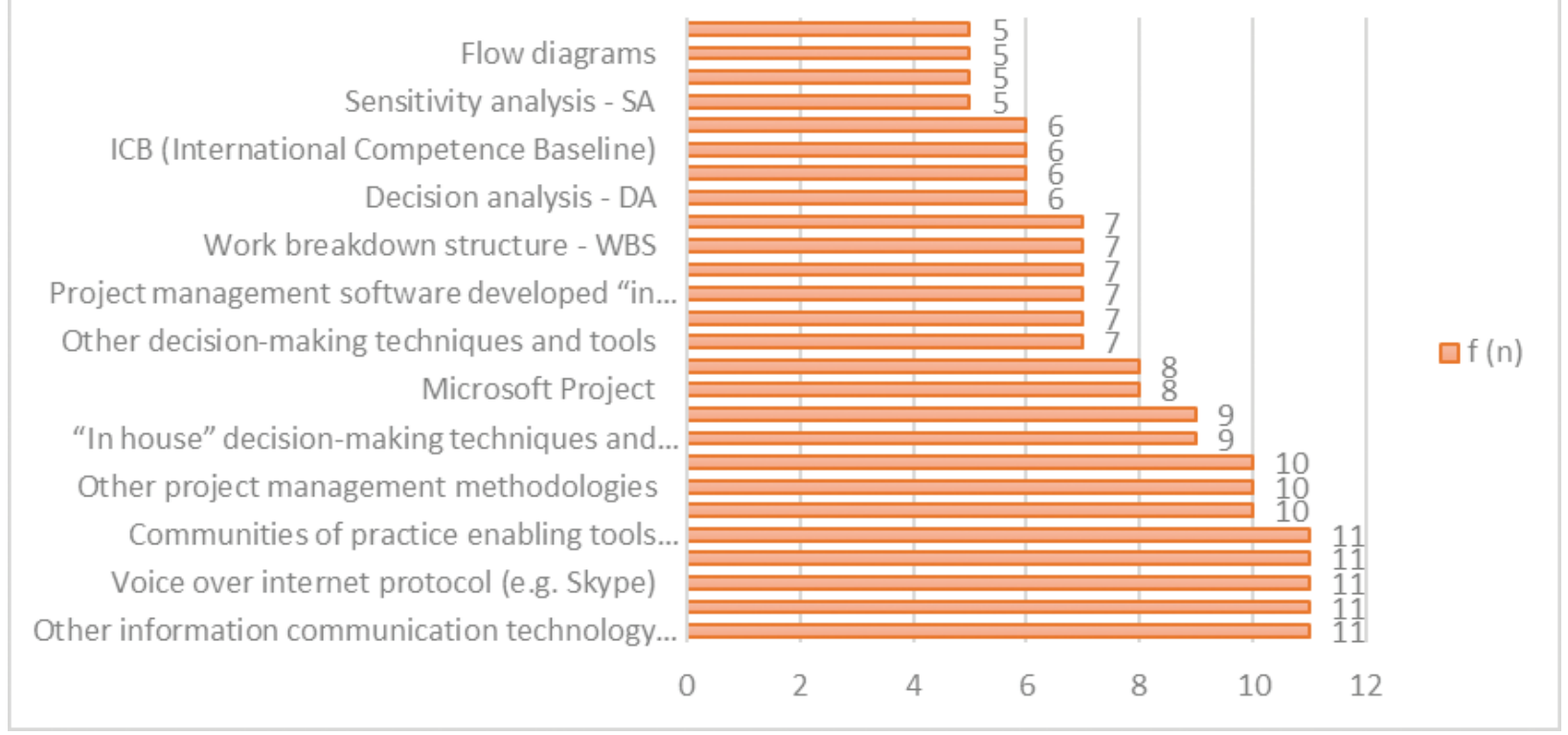

Fig. 3: Frequently used MMTTs. 


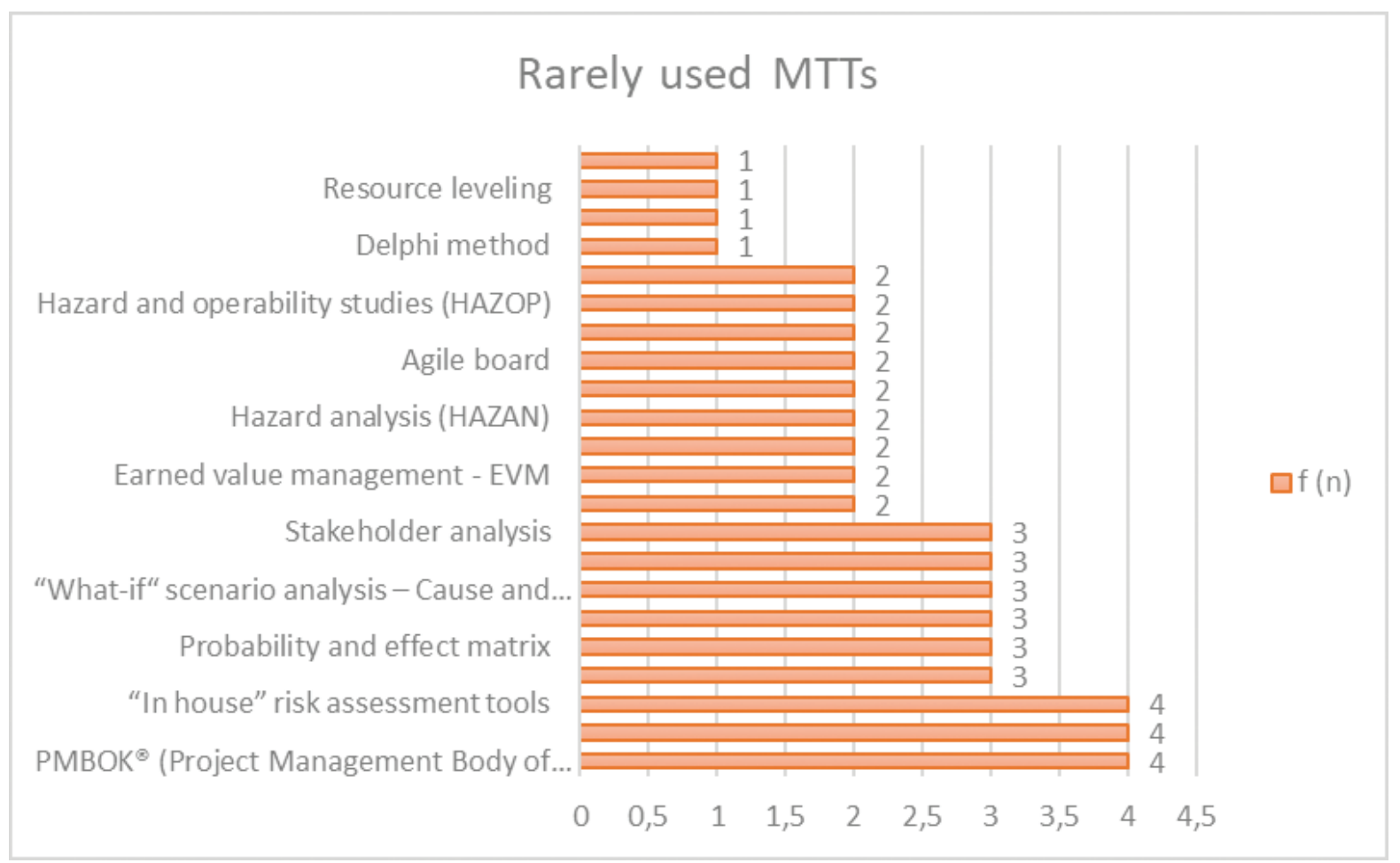

Fig. 4: Rarely used MMTTs.

The average grade of PM success per each project manager $\left(\mathrm{PMS}^{\mathrm{PM}}\right)$ was then linked to his/her grades on MMTTs usefulness (MMTT ${ }^{\mathrm{U}}$ ) by calculating correlation coefficients $r$.

Table 2 shows obtained correlations (where $r>0.5$ ), along with the information on the type of MTTT.

This analysis showed that MMTTs that are used frequently or most often and correlate highly with PM success $(r>0.5)$ are ICB, CPM, organizational breakdown structure (OBS), PERT, sensitivity analysis (SA), risk register, life cycle cost (LCC), PDM, risk assessment and "in house" decision-making techniques and tools (grey ones). Simultaneously, there are some very well-known PM artefacts, such as WBS, Gantt bar chart and progress reports, which project managers use frequently or most often, but results show that they are not highly related to the PM success.

We understand that the results of this study are limited and indicative, due to the sample and the methodology applied; however, we consider it relevant for the MMTTs' further development and application, not only in the observed country.

\section{Discussion}

The conducted study confirmed partly expected results, as well as some new and relevant findings. First of all, all respondents confirmed application and need for MMTTs. This was expected - it would be very unrealistic to even imagine a modern project manager to work without variety of MMTTs. Second, as expected, this study confirmed that majority of project managers often or frequently use the most popular and/or simple artefacts that support their regular work, i.e. communication and administration. Third, the more sophisticated artefacts are on the list of rarely used, which was also expected. Fourth, while extracting particular MMTTs, the most popular are Gantt charts, progress reports, MS Project, etc. which does not surprise (Figures 2 and 3). However, although everything seems logical, when one digs a little bit below the surface, there are many doubts about the justification of the type of MMTT that should be applied, its exact usefulness and its real contribution to the successful work of a project manager. So, we have a "green light" for MMTTs' usage, a "green light" for MMTTs' diversity and a "green light" for MMTTs' usefulness, but real benefits arising from these "green lights" may depend on competences of project manager and maturity of the organization implementing the projects. It seems that internal project factors are more influential in such scenario, and we believed that on the general level our results share similar position as the study from Czech Republic (Doskocil 2015).

On the other hand, there are several unexpected findings obtained from this study. An interesting finding was 
Tab. 2: Correlation of data on the evaluation of PM success and usage of MMTTs

\begin{tabular}{|c|c|c|}
\hline MMTT that project managers use & Correlation $r$ & $\begin{array}{l}\text { Usage level declared } \\
\text { by project managers }\end{array}$ \\
\hline International Competence Baseline & 0.860 & Frequently \\
\hline Critical path method & 0.694 & Frequently \\
\hline Organizational breakdown structure & 0.642 & Frequently \\
\hline Project evaluation and review technique & 0.600 & Frequently \\
\hline Sensitivity analysis & 0.582 & Frequently \\
\hline Risk register & 0.545 & Frequently \\
\hline Life cycle cost & 0.520 & Frequently \\
\hline Precedence diagram method & 0.471 & Frequently \\
\hline "In house" decision-making techniques and tools & 0.462 & Frequently \\
\hline Risk assessment & 0.459 & Most often \\
\hline Groupware (email only) & 0.310 & Most often \\
\hline Cost-benefit analysis & 0.240 & Most often \\
\hline Other information communication technology support tools & 0.207 & Frequently \\
\hline Other risk assessment tools and techniques & 0.184 & Rarely \\
\hline Flow diagrams & 0.173 & Frequently \\
\hline Progress reports & 0.172 & Most often \\
\hline Project goals charter & 0.168 & Most often \\
\hline “In house" project management tools & 0.165 & Frequently \\
\hline Cash flow analysis & 0.164 & Most often \\
\hline Other project management tools & 0.151 & Frequently \\
\hline Team building activities & 0.145 & Frequently \\
\hline PM methodology developed "in house" & 0.114 & Most often \\
\hline Strengths, weaknesses, opportunities and threats analysis & 0.105 & Frequently \\
\hline Work breakdown structure & 0.075 & Frequently \\
\hline Gantt bar charts & 0.062 & Most often \\
\hline Decision analysis & 0.036 & Most often \\
\hline Integrated groupware (email, collaborative tools, shared access to web portals, etc.) & 0.035 & Most often \\
\hline Checklist analysis & 0.023 & Most often \\
\hline "In house" communication and reporting system & 0.021 & Most often \\
\hline
\end{tabular}

obtained from respondents' answers in the first part of the survey, where $84 \%$ of respondents stated that they do not consider MMTTs used in managing their projects adequate to fulfil needs of the sector. Even $94 \%$ of respondents think that certain problems in managing water projects may be minimized by the usage of more adequate MMTTs than the ones being used. In other words, most of the examined project managers think that there is an evident gap among MMTTs being used and those that would be of real help when dealing with problems on projects. The possible reasons for this may vary from missing education, imposed rigid project procedures within an organization, psychological or time-constraining reluctance in learning, developing, testing or accepting new solutions, missing the link between new and creative and current in place, etc. However, project managers are not aware that an easily chosen tool might drive him/her to difficulties and waste of time and energy. We may refer here to the study from Czech Republic where the author stated "in the management of their projects in the context of the application of selected methods, techniques and tools of project management, companies (in the Vysočina Region) make certain mistakes, which have an impact on project success" (Doskocil 2015). 
All respondents use integrated groupware, MS Excel and progress meetings, which is to certain extant similar with results given by Besner and Hobbs (2008), who, among others, found progress reports and PM software used by all respondents in their research. Thereby, the average grade of usefulness of the meetings is 3.90, MS Excel 4.29 and integrated groupware 4.39. The authors believed that these figures are not as big as they could be compared with the wide usage of those methods. What can be done to increase them is to adopt principals of meeting management, maximize possibilities of MS Excel by enhancing the level of users' knowledge and explore further possibilities of cloud management or multidimensional decision-making investment approach on web-based PM solutions in general (Skibniewski and Zhang 2005). In addition, project managers most often use cost-benefit analyses and project goal charters, which is not surprising, since those elements are often mandatory when applying project for some sort of outer financing models, such as those provided by the European Union or World Bank (co-financing is common in water projects).

Reporting on project progress and project issues is immanent to any construction project, especially the complex infrastructural ones, with a large number of stakeholders that all require precise information on timely manner. Reporting systems and progress reports are therefore "a must have" part, but could strive for improvements, due to the comparison of their usage and grades of their usefulness. Also, when having in mind purpose of reporting systems, a parallel with rather poor usage of communication plans and extremely poor usage of stakeholder analysis must be drown. This finding indicates the possibility that project managers in Croatia adopt those tools that are on some level (e.g. state, funding, company) mandatory, without maximization of the purpose and objectives of their usage. Only $9.7 \%$ of respondents use stakeholder analysis, which is important to detect effective communication strategy towards different stakeholders, followed by reporting design. The similar phenomenon may be seen in the usage of Gantt charts and $S$ curves they still remain a traditional popular tool of PM. However, the authors suspected an inadequate usage of their possibilities, especially because WBS (which should precede a creation of a Gantt chart) or critical path method (which is basically a logic behind a Gantt chart as such) is rather modestly used. Their possibilities may be seen in Hwang et al. (2018), who found out that " $S$ curve," "forecasting techniques," "cost control software products" and "WBS" are the popular tools and techniques used for cost control in megaprojects.
When considering modest usage, relatively small number of respondents in the first group (13) use lessons learned technique, which has an extremely high grade of usefulness. This may stress the need of establishing Project Management Offices within companies that will be in charge for data collection, data analysis and recommendations' distribution within PM procedures, methodologies, tools and PM environment overall. Decision trees, already mentioned stakeholder analyses, "what-if" scenario analysis, strengths, weaknesses, opportunities and threats analysis (SWOT) analysis and risk management tools are rarely used. These indicate that project managers do not perceive possible outcomes of their decisions and outer influences on their projects on adequate manner. When it comes to risk management, similar results may be found in Jepson and Kirytopoulos (2018), whose study in Australian construction sector provided evidence that many of the tools promoted by the risk standards/associations do not seem to reflect current project managers' practice.

When making decisions, an interesting information is the one of high grading of "other decision-making techniques and tools." Out of all decision-making techniques and tools that were offered to choose from, respondents graded the "others" category as the highest. This may be one more evidence on the need of development of traditional decision-making tools. When it comes to PM software, respondents most frequently use MS Excel and Primavera, often use MS Project also and are less keen to the usage of other IT tools. Speaking of PM methodologies and standards, respondents mostly use those developed "in house." They often use IPMA ICB, and rarely PMI PMBOK or ISO Guidance on Project Management. No one uses other methodologies (PRINCE, PRINCE 2, P2M/KPM, etc.). Still, earlier study declared that $19 \%$ of respondents who use ICB as the most widespread methodology denote a relatively small figure, regarding the impact ICB could have on PM success (Nahod et al. 2013).

The attempt of our research to link PM success and MMTTs indicates that it is possible to explore such connection. A solid number of PM artefacts that project managers use frequently showed reasonable correlation, mostly those for scheduling and risk analysis. Probably, the highest level of IPMA ICB was influenced by our survey, since we used ICB self-assessment, and therefore brought respondents close to it. High correlation of artefacts focused with time and cost, as well as risk, justify the fact that project managers are very much focused to time and cost overruns. So, each contributing or supportive element has high grade. The surprise that comes from the results is the very low confidence project managers 
have in the contribution of Gantt bar charts, WBS, checklist, decisions analysis, etc., which they use most often. It seems that it confirms the statement above where project managers declared that they do not consider MMTTs used in managing their projects adequate to fulfil their needs. However, according to our outside view, we would say that they might rely too much on a single MMTT and expect unrealistic benefits from its straightforward usage. We did not see comprehensive approach or certain logic in selection of "MMTTs package" that project managers use for endorsing success, but rather traditional approaches, long-term practices, individual judgements, etc., which might indicate rather low PM maturity in their organizations, despite of competent PM individuals. Similar to the military, a battle cannot be won only with the choice of weapons for an individual, especially if that choice is always traditional and without a system that unites everything, adapts and adds new and missing elements with each new battle. So, we believed that MMTTs are valuable and supportive artefact on the way to PM success, but we claimed that additional attention to improve maturity of PM within organizations in the observed environment is needed.

Finally, we can conclude that our pilot study confirmed hypotheses 1 and 3, so as 2 partially, while hypothesis 4 was neither confirmed nor rejected, due to missing cooperation from respondents. According to our subjective assessment hypothesis 4 is also true, but without proper evidence we cannot declare it as a result obtained from this study. Hypothesis 5 might be considered partly proven, under the framework described earlier.

During the update and revision of this article, we presented the key results of this study to three independent higher-level PM expert equivalent to IPMA level A (with more than 20 years of practice) and interviewed them about their opinion. Each from the three experts agreed that results reflect the reality. Experts believed that PM professionals should use more MMTTs, instead of following their own routine and use only those they have already adapted, tested and are being familiar with. Furthermore, experts agreed that simplicity, user-friendly elements and possible tailoring are important features of each MMTT, and it might increase the applicability and facilitate success.

\section{Limitations and suggestions for the further research}

The authors understood that the results of this study are limited and indicative, due to the sample and the methodology applied, but they certainly provide a number of interesting findings which might be inspiration for the further research on the topic, so as for further development and usage of MMTTs, not only in Croatia. As declared in Section 1, this study was conducted within Croatian national context and on one type of infrastructural projects. The results are rough presentation of reality of construction PM in Croatia, where modern PM has no long-lasting tradition and recognition in the engineering sector. The sample size is rather small, which also limits the value of results, so it should be enlarged in the future research. Finally, results are also focused to one type of engineering projects, although currently very dynamic with many large projects. Nevertheless, recommendations drawn out of this study may be useful for the region of central and south-east Europe, since many countries there share similar path of history and recent development trends, particularly about projects and PM profession. Regardless of the described limitations, the idea behind this study and its results, which might be taken as preliminary ones, open the door for similar and more extended studies about MMTTs within the regional context.

\section{Conclusions}

This study investigated the usage and perceived usefulness of PM MMTTs in the infrastructure projects in the Republic of Croatia, on an example of projects from water sector. It confirmed that PM profession needs and uses many MMTTs, rather simpler ones than those too complex. It also showed that too many project managers do not consider MMTTs used in managing their projects adequate to fulfil needs of the sector. Moreover, PM professionals were happy only partially, while considering MMTTs' availability and features. On the other hand, project managers are keen to use exclusively or preferably MMTTs they already adapted, tested and are being familiar with, or those imposed by official procedures within the project organization. Despite of all, there is convergence about MMTTs contribution in project managers' successful work, and consequently in PM success. Regardless of the limitations in the sample and methodology, this study provided significant findings about relationships among project managers, MMTTs and success, which can inspire further more detailed research and lead the PM practice towards more mature PM model. The authors believed that the topic has great potential for the future, particularly the more exact way about relationships and possible dependence between MMTTs usage and creativity or effectiveness of project manager work. What can be seen 
in overall is that not too many PM MMTTs are being used on adequate manner for utilizing all of their capacity. It seems that the role of a project manager is not proactive enough, and there is no strong voice of this profession. Education options are weak point, since many public or private universities do not have courses and programmes on PM areas, despite the fact that one-third of the economy is driven by projects.

\section{Acknowledgement}

The authors would like to thank Croatian waters and Croatian Association for Project Management (CAPM/IPMA Croatia) for support and motivation of this research.

\section{References}

Albert, M., Balve, P., \& Spang, K. (2017). Evaluation of project success: A structured literature review. International Journal of Managing Projects in Business, 10(4), pp. 796-821.

Alotaibi, A. B., \& Mafimisebi, O. P. (2016). Project management practice: redefining theoretical challenges in the 21st century. Project Management, 7(1), pp. 93-99.

Baccarini, D. (1999). The logical framework method for defining project success. Project Management Journal, 30, pp. 25-32.

Besner, C., \& Hobbs, B. (2008). Project management practice, generic or contextual: a reality check. Project Management Journal, 39(1), pp. 16-33.

Blankevoort, P. J. (1983). Management of creativity. International Journal of Project Management, 1(1), pp. 33-36.

Collins, A., \& Baccarini, D. (2004). Project success - A survey. Journal of Construction Research, 5, pp. 211-231.

Crilly, B. (2020). Ambidextrous project management: The influences of leadership styles, project management practices, and team characteristics on creativity and innovation. Doctoral dissertation, Hood College, Maryland.

Davis, K. (2017). An empirical investigation into different stakeholder groups perception of project success. International Journal of Project Management, 35(4), pp. 604-617.

De Wit, A. (1988). Measurement of project success. International Journal of Project Management, 6, pp. 164-170.

Directive 91/271/EEZ, Urban Waste Water Treatment Directive (21.5.1991).

Directive 98/83/EZ, Drinking Water Directive (3.11.1998).

Dobie, C. (2020). Handbook of Project Management: A Complete Guide for Beginners to Professionals, Routledge, Abingdonon-Thames, UK.

Doe, S. R. K. (2017). An Investigation into the Application of Construction Planning Tools and Techniques by Small Scale Contractors in the Ghanaian Construction Industry. Doctoral dissertation, Kwame Nkrumah University of Science and Technology, Ghana.
Doskočil, R. (2015). The level of use of project management methods, techniques and tools and their impact on project success - Selected Region of Czech Republic. Periodica Polytechnica Social and Management Sciences, 24(1), pp. 14-24.

Drob, C., \& Zichil, V. (2013). Overview regarding the main guidelines, standards and methodologies used in project management. Journal of Engineering Studies and Research, 19(3), pp. 26-31.

European Commission, Centre for Excellence in Project Management (2018). PM² Project Management Methodology, Guide 3.0. European Commission, Luxemburg.

Ferreira, M., Tereso, A., Ribeiro, P., Fernandes, G., \& Loureiro, I. (2013). Project management practices in private Portuguese organizations. Procedia Technology, 9, pp. 608-617.

Fortune, J., White, D., Jugdev, K., \& Walker, D. (2011). Looking again at current practice in project management. International Journal of Managing Projects in Business, 4(4), pp. 553-572.

Google Scholar. Available at https://scholar.google.com/ [accessed September, 2020].

Google Search. Available at https://www.google.com/ [accessed September, 2020].

Hariharan, B., \& Arpasuteerat, P. (2017). Combining hard and soft aspects in project performance measurement-a qualitative research undertaken in an agile software development project scenario. Master's thesis, Department of Architecture and Civil Engineering, Chalmers University of Technology, Sweden.

Hugo, F. D., Pretorius, L., \& Benade, S. J. (2018), Some aspects of the use and usefulness of quantitative risk analysis tools in project management. South African Journal of Industrial Engineering, 29(4), pp. 116-128.

Hwang, B. G., Shan, M., Zhu, L., \& Lim, W. C. (2018). Cost control in megaprojects: Efficacy, tools and techniques, key knowledge areas and project comparisons. International Journal of Construction Management (in press).

IPMA - International Project management Association (2018). Proceedings of $6^{\text {th }}$ IPMA Research Conference "Project Management and its Impact on Societies" in Rio de Janeiro, 2018, IPMA, Nijkerk.

IPMA - International Project Management Association. (2006). ICBIPMA Competence Baseline, version 3.0, International Project Management Association, Nijkerk.

IPMA - International Project Management Association. (2015). ICBIPMA Competence Baseline, version 4.0, International Project Management Association, Nijkerk.

Ismael, C. E., \& Raul, P. C. (2019). “Project management Tools and Techniques (T\&T) usage in building sector companies in Cartagena City, T.C.D.” In: Industry, Innovation, and Infrastructure for Sustainable Cities and Communities: Proceedings of the 17th LACCEI International Multi-Conference for Engineering, Education and Technology in Jamaica, 2019, pp. 1-9.

Jensen, A., Thuesen, C., \& Geraldi, J. (2016). The projectification of everything: projects as a human condition. Project Management Journal, 47, pp. 21-34.

Jepson, J., \& Kirytopoulos, K. (2018). Insights into the application of risk tools and techniques by construction project managers. International Journal of Construction Management (in press).

Jovanovic, P., \& Beric, I. (2018). Analysis of the available project management methodologies. Journal of Sustainable Business 
and Management Solutions in Emerging Economies, 23(3), pp. 1-13.

Jugdev, K., Perkins, D., Fortune, J., White, D., \& Walker, D. (2013). An exploratory study of project success with tools, software and methods. International Journal of Managing Projects in Business, 6(3), pp. 534-551.

Leybourne, S., \& Sadler-Smith, E. (2006). The role of intuition and improvisation in project management. International Journal of Project Management, 24(6), pp. 483-492.

Liang, X., Yu, T., \& Guo, L. (2017). Understanding stakeholders' influence on project success with a new SNA method: A case study of the green retrofit in China. Sustainability, 9(10), pp. 1927-1946.

Lordo, R. A. (2001). Learning from data: Concepts, theory, and methods. Technometrics, 43(1), pp. 105-106.

Meredith, J. R., Shafer, S. M., Mantel S. J. Jr., \& Sutton, M. M. (2020). Project Management in Practice. John Wiley \& Sons.

Milosevic, D. (2003). Project Management Tool Box, Tools and Techniques for the Practicing Project Manager. J. Wiley \& Sons, New Jersey.

Mir, F. A., \& Pinnington, A. H. (2014). Exploring the value of project management: Linking project management performance and project success. International Journal of Project Management, 32(2), pp. 202-217.

Morris P. W. G. (2013b). Reconstructing Project Management. Wiley-Blackwell, UK.

Morris, P. W. G. (2002). Science, objective knowledge and the theory of project management. Proceedings of the ICE - Civil Engineering, 150(2), pp. 82-90.

Morris, P. W. G. (2013a). Reconstructing project management reprised: A knowledge perspective. Project Management Journal, 44(5), pp. 6-23.

Munns, A. K., \& Bjeirmi, B. F. (1996). The role of project management in achieving project success. International Journal of Project Management, 14, pp. 81-87.

Musa, M. A., \& Mohammed, M. A. L. (2016). Measuring the attitudes of construction companies towards using project management tools and techniques. Journal of Economic Sciences, 17(1), pp. 154-171.

Nahod, M. M., Vukomanović, M., \& Radujkovic, M. (2013). The impact of ICB 3.0 competences on project management success. Proceedings of Social and Behavioral Sciences, 74, pp. 244-254.

Nieto, R. A. (2012). Global GDP Impact on Projects vs Operations in The Focused organization. Gower, London.

Papke-Shields, K. E., Beise, C., \& Quan, J. (2010). Do project managers practice what they preach, and does it matter to project success? International Journal of Project Management, 28(7), pp. 650-662.

Patanakul, P., lewwongcharoen, B., \& Milosevic, D. (2010). An empirical study on the use of project management tools and techniques across project life-cycle and their impact on project success. Journal of General Management, 35(3), pp. 41-65.
PMI - Project Management Institute (2020). Project Management Body of Knowledge, 7th edn. Project Management Institute, Upper Darby, Philadelphia.

Project Management Blog. (2019). Available at https://www. projectmanager.com/blog/project-management-techniquesfor-every-pm [accessed August, 2020].

Project Management Guide. (2019). Available at: https://www.wrike. com/project-management-guide/ [accessed August, 2020].

Radujković, M., \& Sjekavica, M. (2017). Project management success factors. Procedia Engineering, 196, pp. 607-615.

Radujkovic, M., Car Pusic, D., Ostojic Skomrlj, M., Vukomanovic, M., Burcar Dunovic, I., Delic, D., et al. (2012). Planiranje i kontrola projekata (Project planning and control). University of Zagreb, Faculty of Civil Engineering, Zagreb.

Romero, S. M., Bohorquez, L. F., \& Rojas Puentes, M. P. (2018). Application of project management tools in engineering services companies: Four case studies. Journal of Physics: Conference Series, 1126, pp. 1-6.

Schoper, I. G., Wald, A., Ingason, T. H., \& Fridgeirsson, T. V. (2018). Projectification in Western economies: A comparative study of Germany, Norway and Iceland. International Journal of Project Management, 36, pp. 71-82.

Serrador, P., \& Turner, J. R. (2015). The relationship between project success and project efficiency. Project Management Journal, 46(1), pp. 30-39.

Sjekavica Klepo, M., \& Radujkovic, M. (2019). Early warning system in managing water infrastructure projects. Journal of Civil Engineering and Management, 25(6), pp. 531-550.

Skibniewski, M., \& Zhang, L. (2005). Economic feasibility of web-based project management solutions. International Journal of Construction Management, 5(1), pp. 103-121.

Spundak, M. (2014). Mixed agile/traditional project management methodology - reality or illusion? Proceedings of Social and Behavioral Sciences, 119, pp. 939-948.

Standish Group. (2013). Chaos Manifesto: Think Big, Act Small. Standish Group International Inc.

Sudhakar, G. P. (2016). Understanding the meaning of "Project Success. Binus Business Review, 7(2), pp. 163-169.

Tkalac Vercic, A., Poloski Vokic, N., \& Sincic Coric, D. (2014). Priručnik za metodologiju istraživanja u društvenim djelatnostima. M.E.P., Zagreb.

Tonchia, S. (2018). Project time management. In: Tonchia, S. (ed.), Industrial Project Management. Springer, Berlin, pp. 117-129.

Van Casteren, W. (2017). The waterfall model and the agile methodologies: A comparison by project characteristics. Research Gate, 2, pp. 1-6.

von Bertalanffy, L. (1968). General System Theory: Foundations, Development, Applications. George Braziller, New York.

Zuo, J., Zhao, X., Nguyen, Q. B. M., Ma, T., \& Gao, S. (2018). Soft skills of construction project management professionals and project success factors. Engineering, Construction and Architectural Management, 25(3), pp. 425-442.

Zwikael, O., \& Meredith, J. (2019). When is a project successful? Engineering Management Review IEEE, 47(3), pp. 127-134. 